\title{
RESEARCH
}

Open Access

\section{Spatial distribution of the potential forest biomass availability in Europe}

\author{
Pieter Johannes Verkerk ${ }^{{ }^{*}}$ (D) Joanne Brighid Fitzgerald ${ }^{1}$, Pawan Datta ${ }^{2}$, Matthias Dees ${ }^{2}$, \\ Geerten Martijn Hengeveld ${ }^{3}$, Marcus Lindner ${ }^{4}$ and Sergey Zudin ${ }^{1}$
}

\begin{abstract}
Background: European forests are considered a crucial resource for supplying biomass to a growing bio-economy in Europe. This study aimed to assess the potential availability of forest biomass from European forests and its spatial distribution. We tried to answer the questions (i) how is the potential forest biomass availability spatially distributed across Europe and (ii) where are hotspots of potential forest biomass availability located?

Methods: The spatial distribution of woody biomass potentials was assessed for 2020 for stemwood, residues (branches and harvest losses) and stumps for 39 European countries. Using the European Forest Information SCENario (EFISCEN) model and international forest statistics, we estimated the theoretical amount of biomass that could be available based on the current and future development of the forest age-structure, growing stock and increment and forest management regimes. We combined these estimates with a set of environmental (site productivity, soil and water protection and biodiversity protection) and technical (recovery rate, soil bearing capacity) constraints, which reduced the amount of woody biomass that could potentially be available. We mapped the potential biomass availability at the level of administrative units and at the $10 \mathrm{~km} \times 10 \mathrm{~km}$ grid level to gain insight into the spatial distribution of the woody biomass potentials.
\end{abstract}

Results: According to our results, the total availability of forest biomass ranges between 357 and $551 \mathrm{Tg}$ dry matter per year. The largest potential supply of woody biomass per unit of land can be found in northern Europe (southern Finland and Sweden, Estonia and Latvia), central Europe (Austria, Czech Republic, and southern Germany), Slovenia, southwest France and Portugal. However, large parts of these potentials are already used to produce materials and energy. The distribution of biomass potentials that are currently unused only partially coincides with regions that currently have high levels of wood production.

Conclusions: Our study shows how the forest biomass potentials are spatially distributed across the European continent, thereby providing insight into where policies could focus on an increase of the supply of woody biomass from forests. Future research on potential biomass availability from European forests should also consider to what extent forest owners would be willing to mobilise additional biomass from their forests and at what costs the estimated potentials could be mobilised.

Keywords: Forest biomass, EFISCEN, Europe, Potential supply, Spatial distribution

\footnotetext{
* Correspondence: hans.verkerk@efi.int

${ }^{1}$ European Forest Institute, Yliopistokatu 6B, Joensuu, Finland

Full list of author information is available at the end of the article
} 


\section{Background}

Forests provide many benefits to society through the provisioning of raw materials, food, fuel and many other ecosystem services, including climate regulation, biodiversity protection, soil protection, water regulation, etc. Humans have used forests for centuries to millennia to produce timber for construction and fuelwood for heating and cooking. However, the use of fuelwood in particular has diminished during the last two centuries due to the availability of fossil fuels. In an effort to mitigate climate change and reduce the dependency of humans on fossil fuels or fossil-intensive materials, there is a growing interest again in forests as a resource to supply a future bio-economy (e.g., Scarlat et al. 2015; Koukios et al. 2017; Lainez et al. 2017; Bell et al. 2018). Forest biomass may be used as a bio-energy feedstock replacing fossil fuels (e.g. coal, oil and gas), although its climate benefits are subject to debate (see e.g., Searchinger et al. 2018). Forest biomass may also be used for producing materials and provide climate benefits by storing carbon in wood products (Brunet-Navarro et al. 2017), or substituting for energy-intensive, alternative products such as concrete and steel (Sathre and O'Connor 2010). Emerging markets for forest-based products include construction, packaging, textiles, chemicals, polymers, liquid biofuels, as well as a number of niche markets such as cosmetics, food additives, and pharmaceuticals (Sillanpää and Ncibi 2017). These emerging markets require raw material from the forests and it is therefore important to quantify how much of the forest resource is potentially available for use, and where this resource is located.

Current levels of global annual wood production amount approximately to 3.7 billion $\mathrm{m}^{3} \cdot \mathrm{yr}^{-1}$ (FAOSTAT 2018). However, wood production is not distributed equally across forest landscapes and is often concentrated in particular locations or regions (Masek et al. 2011; Wendland et al. 2011). For example, in Europe approximately 490 million $\mathrm{m}^{3}$ roundwood is currently being harvested annually (FAOSTAT 2018), typically from forests of coniferous tree species located in accessible and productive areas (Levers et al. 2014; Verkerk et al., 2015a). However much of these forests are already utilised and in order to meet the increased future demands of wood or biomass, it may help to identify where the resource may be under-used to understand better where policies could best be targeted to increase the mobilisation of the forest resource.

To understand to what extent forests can supply raw materials to produce materials and renewable energy in the future, many assessments have been carried out that attempted to quantify biomass potentials from forests at sub-national to the global level (Smeets and Faaij 2007; de Wit and Faaij 2010; UNECE-FAO 2011; Verkerk et al. 2011; Díaz-Yáñez et al. 2013; Tum et al. 2013; Lauri et al. 2014; Lundmark et al. 2015; Daioglou et al. 2016; Di
Fulvio et al. 2016; Mansuy et al. 2017; Mola-Yudego et al. 2017; Burg et al. 2018; Jonsson et al. 2018). These studies typically estimate a maximum, theoretical amount of biomass that could potentially be available and then consider constraints that may reduce the potential availability (Vis and Dees 2011). In general, these assessments indicate that under the premise of a maximum, sustained harvest level, more woody biomass could be mobilised from forests as compared to current utilisation levels. Unfortunately, only a few studies (e.g., Lundmark et al. 2015; Mansuy et al. 2017; Burg et al. 2018) have so far assessed how the potential biomass supply is spatially distributed across forested landscapes, but information on the spatial distribution of the potential availability of forest biomass does not exist at the pan-European-level. However, such information is important to determine to what extent these potentials can be mobilized. Local environmental conditions are important factors affecting harvesting probabilities (Antón-Fernández and Astrup 2012; Kilham et al. 2018) and possibilities (Verkerk et al., 2015b). Furthermore, local environmental conditions are important factors in determining supply costs, as they affect the choice of harvesting technology and machinery that can be used to mobilise forest biomass and the transportation costs (de Wit and Faaij 2010; Lauri et al. 2014; Di Fulvio et al. 2016). The spatial distribution of forest biomass potentials across the landscape is thus an important factor in determining whether these potentials could be mobilised.

In this study, we estimated the woody biomass potentials from forests available for wood supply (including stemwood, logging residues (i.e. branches and harvest losses) and stumps (including coarse roots)) in 39 European countries by 2020 . This study aimed to assess the potential availability of forest biomass from European forests and its spatial distribution. We tried to answer the questions (i) how is the potential forest biomass availability spatially distributed across Europe and (ii) where are hotspots of potential forest biomass availability located?

\section{Methods}

\section{Forest biomass quantification}

To estimate potential forest biomass availability, we followed the approach described and applied by Verkerk et al. (2011). We extended their analysis from 27 to 39 European countries and compiled an updated dataset on forest resource information to estimate the theoretical potential of forest biomass supply, i.e. the overall, maximum amount of forest biomass that could be harvested annually within fundamental bio-physical limits. This theoretical potential relates to the maximum productivity under theoretically optimal management taking into account limitations that result from soil, temperature, solar radiation and rainfall (Vis and Dees 2011). Our estimated biomass potentials include stemwood, logging residues 
(i.e. branches and harvest losses) and stumps for the 28 European Union member states, Albania, Bosnia and Herzegovina, Kosovo, Moldova, Montenegro, Macedonia, Norway, Serbia, Switzerland, Turkey, and Ukraine.

For 31 countries, we compiled detailed information on area, growing stock and net annual increment, structured by age-class and forest type (defined as a combination of administrative regions, owners, site-class and tree species) from national forest inventories. We used data from the European Forest Sector Outlook Study II (UNECE-FAO 2011) and collected updated information for eight countries (Austria, Czech Republic, Finland, Germany, Ireland, the Netherlands, Ukraine and United Kingdom) from the internet and by approaching national correspondents and agencies. We attempted to obtain these data following common definitions, but did not make further attempts to harmonize the data to avoid or reduce the effects of differences between definitions applied in national forest inventories (Tomppo et al. 2010).

We used this information to initialise the European Forest Information SCENario model (EFISCEN; version 4.1) (Sallnäs 1990; Verkerk et al. 2016). EFISCEN is a large-scale forest resource model that projects forest resource development at regional to national level and can be used to estimate the theoretical potential of forest biomass supply, based on the age-structure, growing stock and increment of the resource and controlled by management actions. A basic management regime defines the period during which thinning can take place and a minimum age for final felling. These regimes can be regarded as constraints on the total harvest level and they were defined based on forest management regimes according to handbooks and national experts (Nabuurs et al. 2007; UNECE-FAO 2011). For countries where inventory data referred to the state of the forests before 2010 (see Dees et al., 2017a), we ran EFISCEN until 2010 using historical roundwood production (FAOSTAT 2015) to which we added 12\% bark (UNECE-FAO 2010). To estimate the theoretical forest biomass potential, the EFISCEN model was subsequently used to iteratively assess the theoretical felling potential of stemwood for 2020 (see Verkerk et al. 2011 for details). To correct for harvesting losses, we used data on fellings and removals (UNECE-FAO 2000) to calculate the fraction of harvest losses for coniferous and broadleaved species separately and used this information to estimate the amount of stemwood that could be removed as logs during thinnings and final fellings. Harvest losses together with branches represent logging residues and can, along with stumps, also be extracted. The amount of branches, stumps and coarse roots was estimated from stemwood volume (incl. Harvest losses) using species-specific wood density factors (IPCC 2003) and age-dependent, species-specific biomass allocation factors (see Verkerk et al. 2011 for details).
EFISCEN could not be applied for Cyprus, Greece, Montenegro, Macedonia, Bosnia and Herzegovina, Kosovo, Malta and Serbia due to absence of the required forest inventory data. Instead, we assumed that the theoretical potential of forest biomass supply equals the net annual increment corrected for harvesting losses (Vis and Dees 2011). We used aggregated data on forest area, growing stock and net annual increment, for conifers and non-conifers separately, from Forest Europe et al. (2011), Forest Europe (2015). We used biomass allocation functions from Teobaldelli et al. (2009) and estimated stump biomass based on data by Asikainen et al. (2008).

\section{Spatial disaggregation}

The spatial resolution of the estimated potentials is determined by the resolution of the forest inventory data that we used to calculate the biomass potentials, which ranged in our case from the level of administrative regions to national level. However, for the 31 countries where we applied EFISCEN, the estimated potentials are based on estimations for individual tree species. To disaggregate our biomass potentials from regional to national level to the grid level, we therefore linked the information on tree species in EFISCEN with spatially explicit tree species distribution maps by Brus et al. (2012) at $1 \mathrm{~km} \times 1 \mathrm{~km}$ resolution. We did this based on the proportion of forest cover of a particular tree species in a pixel to the total area covered by that tree species in that region or country. For countries where we could not apply EFISCEN, we applied a similar approach and disaggregated biomass potentials based on the spatial distribution of conifer and non-conifer tree species. With this approach, we were able to refine the effect of the constraints on biomass extraction compared to Verkerk et al. (2011).

\section{Biomass potential typology}

The estimated forest biomass potentials represent a theoretical potential as they are higher than what can be supplied from the forest due to environmental, social, technical, and economic constraints on wood supply. We estimated the forest biomass potential according to the following potential types (Dees et al., 2017b; Panoutsou 2017):

- Base potential (BASE): the potential most closely aligned to current guidelines of sustainable forest management. This also covers legal restrictions such as restrictions from management plans in protected areas;

- Technical potential (TECH): the absolute maximum amount of ligno-cellulosic biomass potentially available assuming the absolute minimum of technical constraints;

- High potential (HIGH): a potential with fewer constraints than the BASE potential, assuming a strong focus on the use of wood for producing energy and other uses. It includes a strong 
mechanisation of harvesting across Europe and assumes less restrictive biomass harvesting guidelines, e.g. stumps from final fellings are considered to be available in all countries.

- Potential with enhanced biodiversity protection (BIOD): a potential similar to the BASE potential, but assuming that the forest available for wood supply is effectively reduced by $10 \%$ due to an expanded protected forest area, and an increase in the extent of retention trees.

To quantify these four biomass typologies, we combined our theoretical potential with a set of constraints that reduce biomass availability. We considered the following constraints (Verkerk et al. 2011; Dees et al., 2017a):

- Site productivity, which limits residue extraction on poor soils;

- Soil and water protection, which limits residue extraction to prevent erosion, soil compaction and water pollution;

- Biodiversity protection, which reduces stemwood and residue extraction to prevent loss of biodiversity;

- Recovery rate, which limits residue extraction level based on slope and machinery;

- Soil bearing capacity, which limits mechanised harvesting of biomass on certain soil types;

Each of the constraints was quantified separately for the type of biomass (i.e. stemwood, logging residues, and stumps) and by type of felling activity (i.e. thinnings and final felling) for the different biomass potential typologies (see Dees et al., 2017a for details). We compiled a raster layer for each constraint and estimated the lowest, permitted extraction rate according to each potential type.

To estimate the constrained biomass potential for each biomass type, we multiplied the gridded constraint maps with the disaggregated woody biomass potential maps to estimate the BASE, TECH, HIGH and BIOD potentials. All potential biomass sources were aggregated to the level of regional administrative units following the Classification of Territorial Units for Statistics (NUTS; Nomenclature des Unités Territoriales Statistiques) levels 2 and 3. The map for the BASE potential was also produced at a resolution of $10 \mathrm{~km} \times 10 \mathrm{~km}$. In our study, we focused on the BASE potential and used the other three potential types to assess how our assumptions would influence the estimated biomass availability at European level.

\section{Measures for expressing biomass availability}

Here we expressed biomass availability as total biomass availability (Tg dry matter per year, Tg.yr. ${ }^{-1}$ ) and relative biomass availability (ton dry matter per ha land area and per year, tha ${ }^{-1} \cdot \mathrm{yr}^{-1}$ ). In addition, we calculated additional attributes of the spatial distribution of biomass availability:

- unused forest biomass potential expressed per unit of land (ton dry matter per ha land area and per year, $\left.\mathrm{t} \cdot \mathrm{ha}^{-1} \cdot \mathrm{yr}^{-1}\right)$. We calculated the average (sub-national) roundwood production for 2000-2010 (Verkerk et al., 2015b; FAOSTAT 2018) and converted these to dry matter biomass values using basic wood densities ( $415 \mathrm{~kg} \cdot \mathrm{m}^{-3}$ for conifers and $542 \mathrm{~kg} \cdot \mathrm{m}^{-3}$ for non-conifers; Dees et al., 2017a) and deducted this from our estimated total biomass potential. Roundwood production data were not available for Croatia, Kosovo, Turkey and Ukraine at the appropriate resolution;

- proportion of forest biomass in total ligno-cellulosic biomass potential in the region (\%.yr. $\left.{ }^{-1}\right)$. We collected information on ligno-cellulosic biomass potentials from other sources (agricultural residues, wood processing industry, municipal waste, post-consumer wood) for 2020 from Dees et al. (2017b) and estimated the proportion coming from forests. Information on ligno-cellulosic biomass potentials from other sources at sub-national level was not available for Norway and Switzerland.

To summarize information on these measures of potential forest biomass availability, we highlight hotspots, which we defined as NUTS- 2 regions with the $25 \%$ largest values in biomass availability for each of the measures of forest biomass availability. Kosovo, Norway, Serbia, Switzerland, Turkey and Ukraine were excluded from this hotspot analysis due to missing data for at least one of the four measures of forest biomass availability.

\section{Results}

The total forest biomass potential (BASE potential) for all 39 countries was estimated at $401 \mathrm{Tg}$ dry matter per year $\left(\right.$ Tg.yr. $\left.^{-1}\right)$. As shown in Fig. 1, the majority (88\%) of this potential is composed of stemwood, while residues and stumps contribute $11 \%$ and $1 \%$, respectively. The potential forest biomass availability in the 28 European Union member states accounted for $84 \%$ of the potential for all 39 countries in our study and approximately half of the total European forest biomass potential is located in just five countries (Sweden, Germany, France, Finland and Poland).

The total availability of forest biomass strongly depended on the biomass potential type that is considered; for the TECH, HIGH and BIOD biomass typologies, we estimated a potential biomass supply of 551, 475 and $357 \mathrm{Tg} \cdot \mathrm{yr}^{-1}{ }^{-1}$, respectively. The larger potential supply estimated for the TECH and HIGH biomass potentials (as compared to the BASE potential) are entirely 


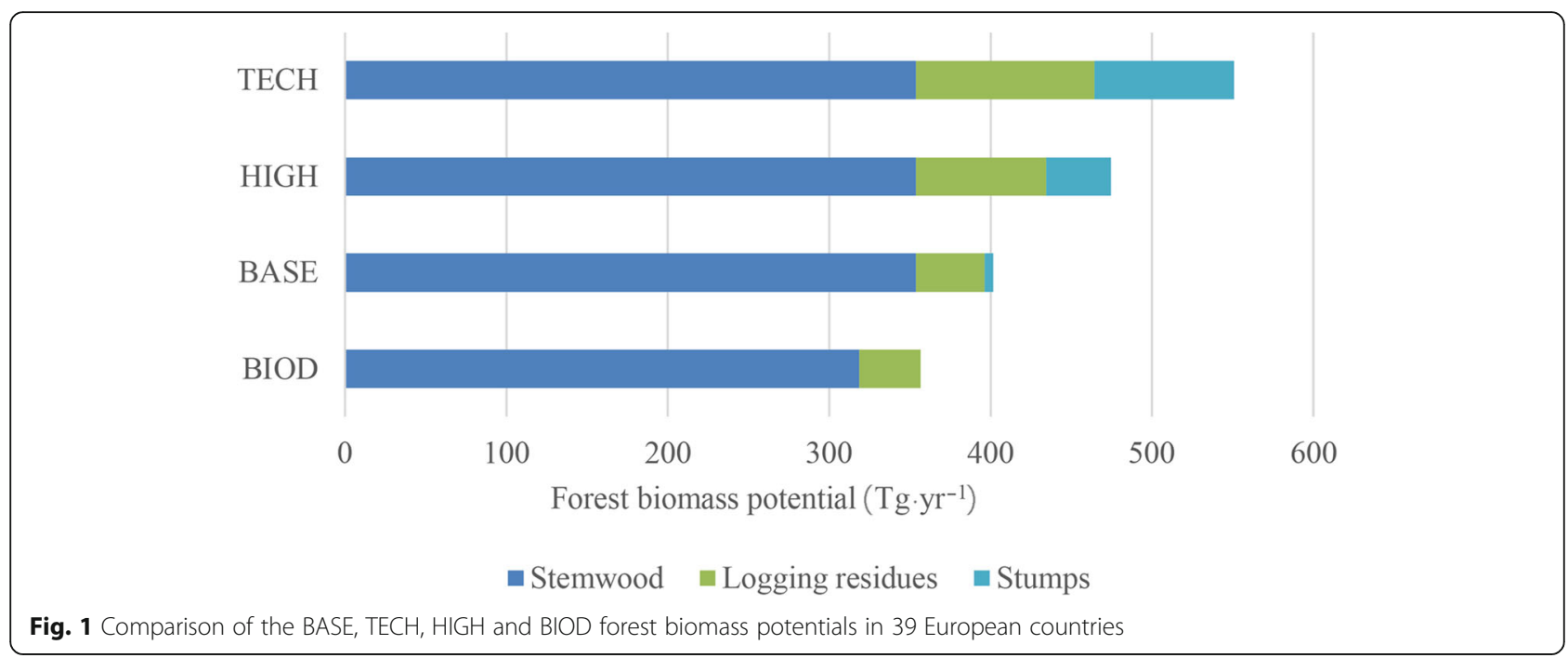

due to less stringent assumptions affecting the supply of logging residues and stumps. For the BIOD biomass potential, the availability of all biomass types is reduced compared to the BASE potential (Fig. 1).

Figure 2 shows the spatial distribution of potential forest biomass availability at three levels of spatial detail. Regardless of the level of spatial detail, our results suggest that the largest potential supply of woody biomass per unit of land can be found in parts of northern Europe (southern Finland and Sweden, Estonia and Latvia), central Europe (Austria, Czech Republic, and southern Germany), southwest France and Portugal. The estimates of biomass availability at grid and NUTS-3 level indicated that regions with low forest biomass potentials are located in northern parts of Norway, Netherlands, northern Belgium, central Spain, southeast Ukraine and central Turkey. These patterns were less distinct when presenting biomass potentials at NUTS-2 level.
The spatial patterns with large woody biomass potentials in northern Europe, central Europe, southwest France and Portugal remained visible when expressing biomass availability as proportion of total ligno-cellulosic biomass availability (Fig. 3). Conversely, when estimating the unused biomass availability, especially regions in Finland, southern Sweden and southwest France were no longer among the regions with most woody biomass being available, with central Portugal and central parts of Europe being more prominent (Fig. 3A).

The observed patterns of biomass availability were emphasized when highlighting hotspots in biomass availability (Fig. 4). 24\% of the regions were identified as hotspot for at least two of the measures of biomass availability and $11 \%$ with being a hotspot for all three measures of biomass availability. Regions that were classified as hotspots for all three measures were located in central Sweden, Estonia, Latvia, Austria, northern Italy,

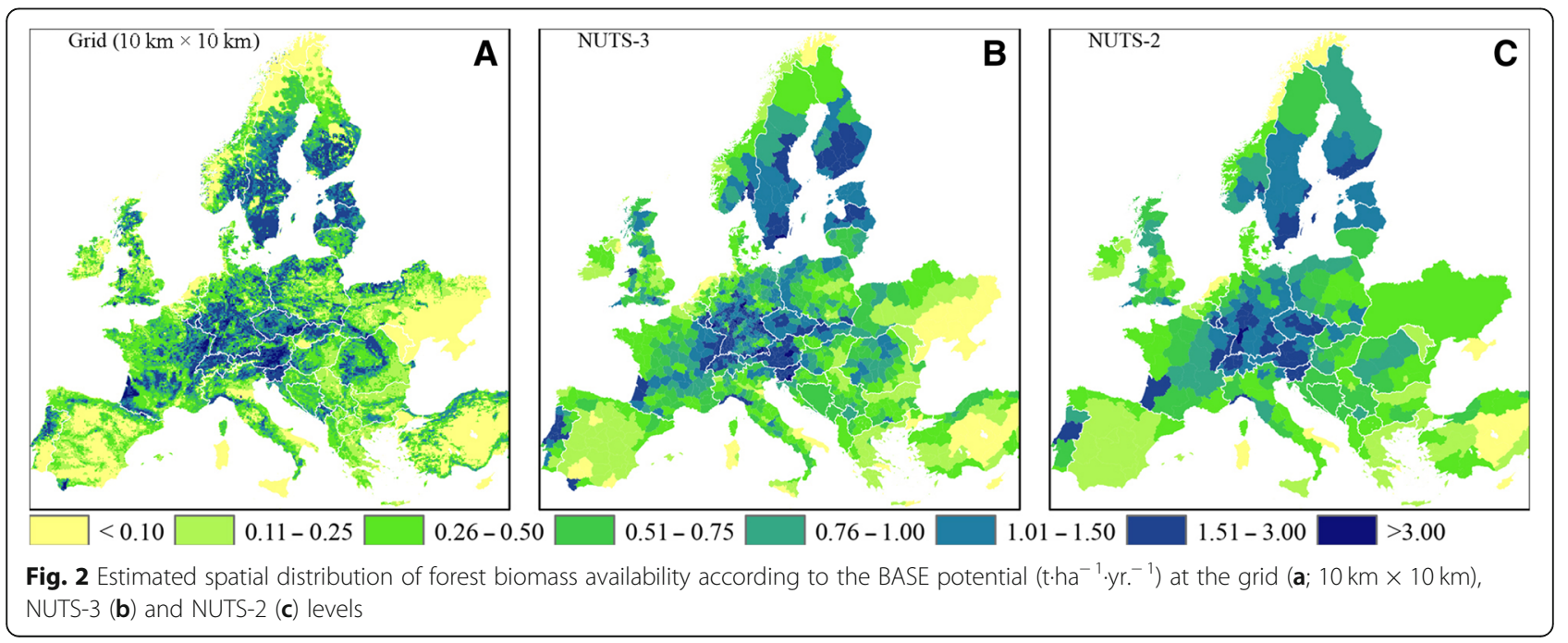



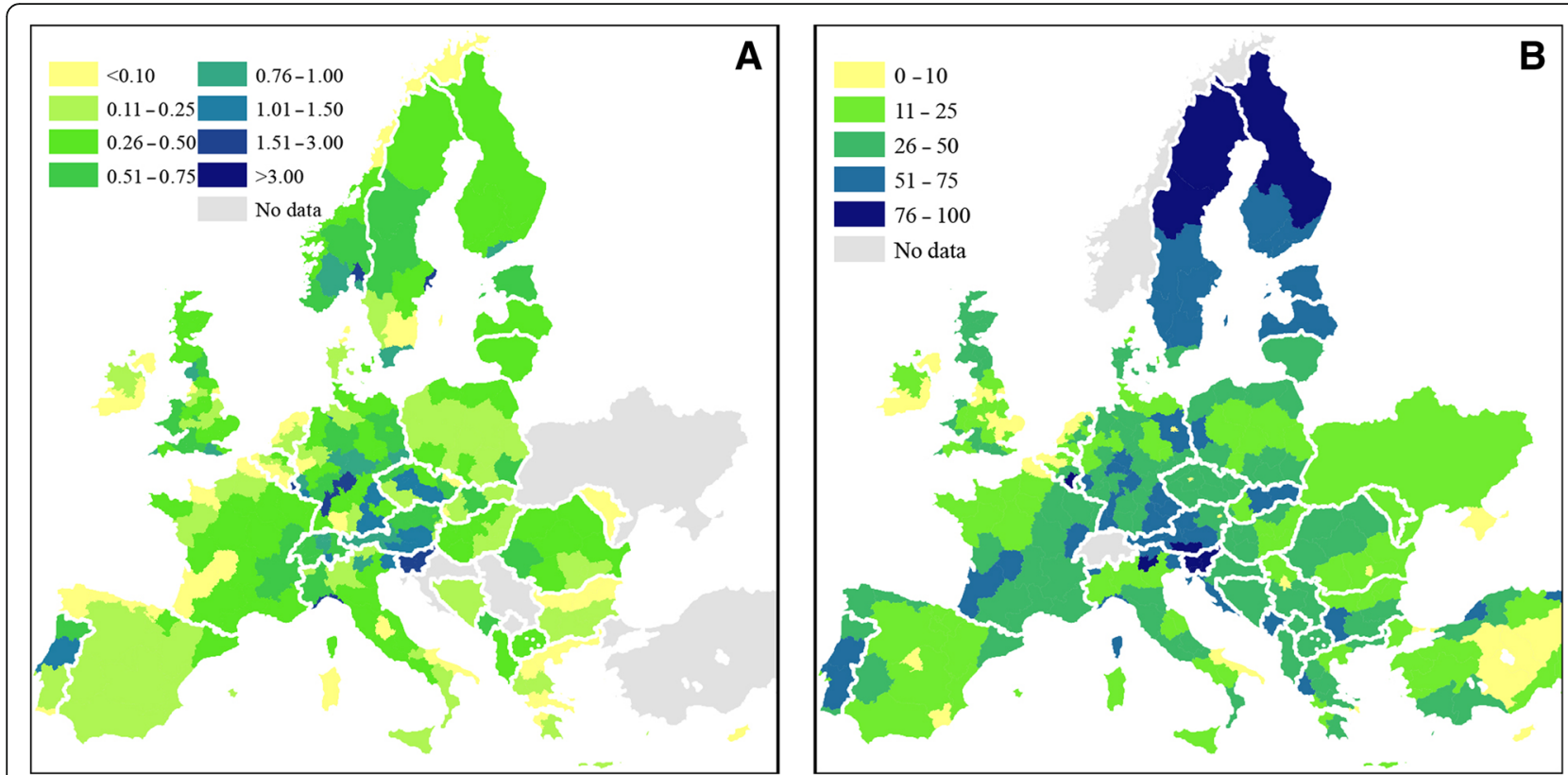

Fig. 3 Estimated forest biomass availability according to the BASE potential at NUTS-2 level, expressed as unused potential per unit of land $\left(\mathbf{a}\right.$; tha ${ }^{-1} \cdot \mathrm{yr}^{-1}{ }^{-1}$ ) and as proportion of total ligno-cellulosic biomass potential in the region $\left(\mathbf{b} ; \% \cdot y r^{-1}\right)$

Slovenia and central parts of Portugal. In contrast, we identified generally no hotspots of biomass availability in the Mediterranean region or the coastal regions ranging from Denmark to northwest France.

\section{Discussion}

\section{Biomass availability}

Here we presented the results of an assessment of the potential forest biomass availability in Europe and we provided insight into how these forest biomass potentials are spatially distributed across the continent. According to our calculations for the BASE scenario in 2020, forests in 39 European countries could provide $401 \mathrm{Tg} \cdot \mathrm{yr} .^{-1}$ of biomass. Out of this potential, $354 \mathrm{Tg} \cdot \mathrm{yr}^{-1}{ }^{-1}$ would be available as stemwood. The current, reported roundwood production in these 39 countries amounted to 582 million $^{3} \cdot \mathrm{yr}^{-1}$ in- $^{-}$ cluding bark over the period 2011-2016 (FAOSTAT 2018; assuming a bark fraction of $12 \%$ ), which would correspond to $268 \mathrm{Tg} \cdot \mathrm{yr}^{-1}$. Reported roundwood production may, however, underestimate the real production volumes (e.g., Jochem et al. 2015) and findings on the dimension of the unused harvesting potential have to be interpreted with caution. Nevertheless, our assessment corroborates previous studies suggesting that more biomass could be mobilised as compared to currently reported utilisation levels.

Our study builds strongly on the work by Verkerk et al. (2011). The main improvements are firstly that our study shows how these biomass potentials from forests are spatially distributed across the European continent, thereby providing insights into which European regions could increase the supply of woody biomass from forests and could be a focus of targeted policies. Secondly, we collected and used updated forest resource information for eight countries. Such updates are important as several European countries are improving their forest inventory methods (e.g., by moving from stand-wise inventories to statistical inventories) (Tomppo et al. 2010) and are harmonising important parameters to enhance the comparability of forest resource information between countries (Alberdi et al. 2016; Fischer et al. 2016). Thirdly, we considered a larger number of countries and estimated biomass availability in the European Union, as well as 11 other European countries. Fourthly, we used a biomass potential typology, which has also been applied to estimate ligno-cellulosic biomass potentials from agriculture and waste (Dees et al., 2017a; Panoutsou 2017). Using a common typology facilitates an assessment of the extent that forest resources can contribute to policy targets, in conjunction with biomass from other sectors.

Several previous studies have been conducted to estimate biomass availability from forests, which mainly focused on the 28 European Union member states. For these 28 countries, we estimated the forest biomass potential from stemwood, logging residues and stumps at 338 Tg.yr. ${ }^{-1}$, or 737 million $\mathrm{m}^{3} \cdot \mathrm{yr}^{-1}$. This is similar to the 744 million $\mathrm{m}^{3} \cdot \mathrm{yr}^{-1}{ }^{-1}$ estimated by Verkerk et al. (2011), less than the 795 million $\mathrm{m}^{3} \cdot \mathrm{yr}^{-1}$ estimated by Jonsson et al.

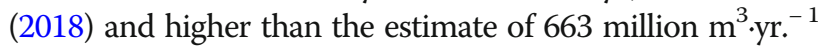
by Di Fulvio et al. (2016). Differences between studies arise from differences in data sources (e.g., forest inventory data, forest area), biomass types considered and on assumptions 

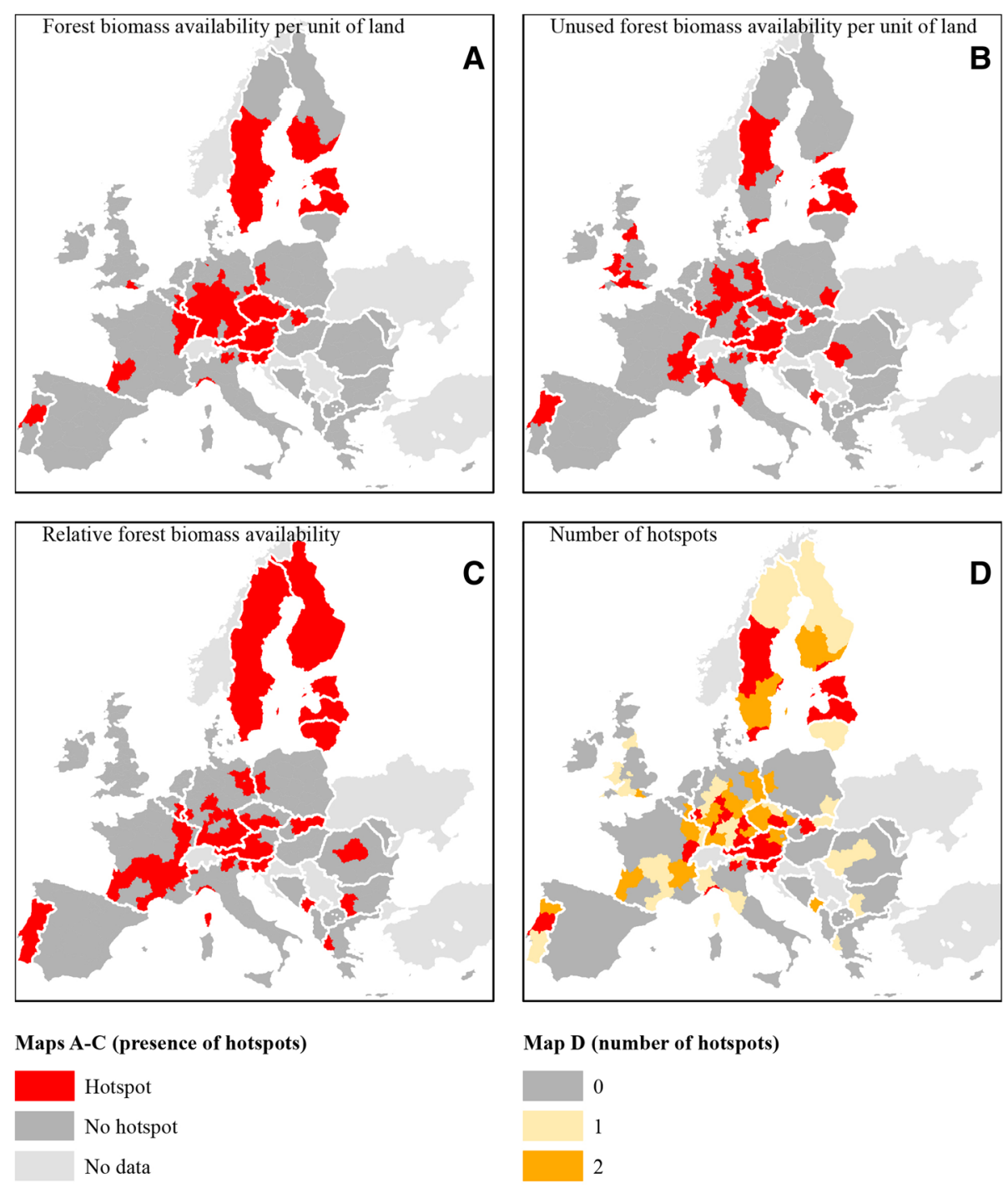

Map D (number of hotspots)

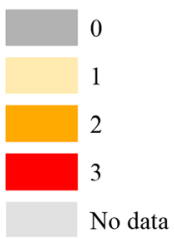

Fig. 4 Hotspots (i.e. NUTS-2 regions with the 25\% largest values) in forest biomass availability according to the BASE potential when expressing biomass potentials per unit of land (a), unused potential per unit of land (b), as proportion of total ligno-cellulosic biomass potential in the region (c) and the total number of hotspots per region (d)

made with regards to the availability of biomass. Indeed, our study showed that the consideration of constraints can have a large effect on the extent that biomass is available, especially with regards to the availability of logging residues and stumps. Compared to the study by Verkerk et al. (2011), we did not consider social factors that may limit mobilisation of woody biomass potentials. Instead, we followed a recently developed biomass typology (Dees et al., 2017a; Panoutsou 2017), which considers only technical and environmental aspects that could limit biomass availability. Nevertheless, we consider the attitude of forest owners as a crucial but uncertain factor in determining whether these potentials can be mobilised. Based on a survey of private forest owners in Germany, Portugal and Sweden, Blennow et al. (2014) argue that European private forest owners may not be able to contribute to mobilising large amounts of stemwood for energy purposes. However, the authors focused on stemwood and did not investigate the attitude of forest owners to supplying logging residues and stumps for energy purposes. In contrast, findings in other regions of the continent show a relatively high degree of willingness of forest owners to manage their forests for producing woody biomass for energy purposes (Stjepan et al. 2015). Altogether, this suggests that generalising the behaviour of forest owners across the continent is complicated and may be regionally different. Future research 
could focus if and how forest owners could be motivated to mobilise additional forest biomass. Future research should also consider at which costs biomass could be mobilised. Combining our results with detailed spatial information on end-use facilities and transport networks (Di Fulvio et al. 2016) would enable estimating at which cost levels forest biomass can be mobilised in Europe.

An important question is whether the estimated forest biomass potentials represent a sustainable potential. In our study, we focused on biomass potentials from forests available for wood supply and we are therefore not considering harvesting in strictly protected forests and forests where harvesting is not allowed or not possible. Furthermore, we estimated a harvest level that could be sustained for several decades and considered multiple environmental factors that reduce biomass availability to avoid detrimental effects on forests. However, this does not necessarily imply that substantially increasing harvesting levels would be sustainable in all aspects. A key issue is whether using forest biomass contributes to climate change mitigation, but this strongly depends on how wood is used. Numerous studies (for an overview, we refer to Searchinger et al. 2018) argue that burning wood may - at least temporarily - increase carbon in the atmosphere before it is absorbed again by the re-growing trees. Using wood for materials, however, could result in lower emissions as compared to alternative, fossil-intensive materials (Sathre and O'Connor 2010; Leskinen et al. 2018). The overall climate change mitigation effects of using wood should consider the carbon balances in forest ecosystems, harvested wood products and substitution effects (Leskinen et al. 2018). Increasing harvest levels may also affect forest biodiversity. Intensively managed areas generally contain less features important for biodiversity as compared to unmanaged (Paillet et al. 2010) or less intensively managed forests (Wallenius et al. 2010; Brukas et al. 2013). Increasing harvesting intensity may negatively affect biodiversity (Bouget et al. 2012) as well as other functions and services provided by forests (Sing et al. 2018), although increasing harvest intensity may also have positive effects by improving early seral habitat conditions and by increasing light availability, which allows for a more complex understory vegetation to develop (Vance et al. 2018). In addition to stemwood, also the extraction of logging residues may lead to negative trade-offs with biodiversity (Jonsell 2008; Bouget et al. 2012; Ranius et al. 2018). Furthermore, logging residue extraction could lead to reduced nutrient availability in forest soils, which may have negative consequences on future tree growth (Achat et al., 2015a; Achat et al., 2015b; Ranius et al. 2018). Especially the extraction of stumps is disputed, as stump extraction could have adverse impacts on forest soil carbon stores and greenhouse gas emissions; disturbance of soil structure leading to increased risk of soil erosion, increased soil compaction, depleted soil nutrient stocks, and changes in nutrient cycling might impact on future productivity and lead to loss of valuable habitats (Walmsley and Godbold 2010; Vanguelova et al. 2017). We attempted to consider these aspects in the definitions of the constraints applied to the extraction of logging residues and stumps following the definition of the biomass typologies (Dees et al., 2017a; Panoutsou 2017), but this does not mean there will not be any negative impacts of increasing harvesting levels.

\section{Spatial distribution of biomass availability}

Our study provided insight into how the forest biomass potentials are spatially distributed across the European continent. We presented potential biomass supply at the $10 \mathrm{~km} \times 10 \mathrm{~km}$ grid level and at two administrative levels (i.e. NUTS 2 and 3), but it was not possible to assess the accuracy of our maps as data or maps to validate our assessments do not exist. As such, the quality of our maps can merely be assessed based on the quality of the data sources and methodology used in our study and by comparing the estimated forest biomass potentials with other studies. We consider that the grid level provides the most detailed insight into spatial distribution of the estimated potential biomass supply but is most prone to inaccuracies and these results should therefore be interpreted with care. Across all three levels of spatial detail, we identified rather consistent patterns in regions having the largest biomass potentials, but the consistency was less clear for regions with low potential biomass availability with some areas not appearing to show low availability when the data was presented at NUTS 2 level.

Our results suggest that the largest total forest biomass potentials per unit of land can be found in northern Europe (southern Finland and Sweden, Estonia and Latvia), Central Europe (Austria, Czech Republic and southern Germany), Slovenia, southwest France and Portugal. Several factors may explain these patterns. Regions in northern Europe, as well as Slovenia, can be generally characterised by having a high forest cover (Forest Europe 2015), which results in large forest biomass potentials per unit of land. Central European regions have generally lower forest cover, but growth conditions generally favour higher biomass stocking (Gallaun et al. 2010; Thurner et al. 2013; Moreno et al. 2017) and increment rates (Neumann et al. 2016; Schelhaas et al. 2018) and thereby account for larger forest biomass potentials per hectare of forest. Southwest France and Portugal exhibit also high increment rates and these are closely linked to the presence of intensively-managed plantations of Maritime pine (Pinus pinaster Ait.) and Eucalyptus species, respectively (Brus et al. 2012; San-Miguel-Ayanz et al. 2016).

The presence of hotspots of forest biomass availability in northern Europe, Central Europe, southwest France 
and Portugal overlaps to certain extent with observed patterns in wood production (Verkerk et al., 2015a). Indeed, when we contrasted the hotspots for regions with biomass availability and unused biomass availability (Fig. 4a and b), we observed only a partial overlap of hotspots; hotspots in forest biomass potential in Finland, southwest France and parts of Sweden and Portugal disappeared when we deducted biomass that is already harvested. This finding indicates that these regions may not be able to produce large quantities of forest biomass in addition to current production levels, without changes in forest management practices (e.g. species selection, tree breeding and provenance selection, etc.) that could enhance biomass production in the future (Rytter et al. 2016). Conversely, when deducting wood already harvested from the total potential, new hotspots appeared in the United Kingdom, as well as in Alpine regions of France and Italy. These results indicate that the location of unused biomass potentials only partially coincide with regions that currently have high levels of wood production and infrastructure to process wood.

With the exception of Portugal, we identified no hotspots of biomass availability in the Mediterranean region. The generally low biomass potentials estimated for the region may be linked with the use of the EFISCEN model. This model was developed to address even-aged forest systems, while a substantial share of Mediterranean forests have an uneven-aged forest structure (Forest Europe 2015), which renders our model projections less reliable for this region. However, low forest management activity (Levers et al. 2014) and dry conditions during summer generally result in low increment rates in the region (Neumann et al. 2016; Schelhaas et al. 2018), which could also explain the limited forest biomass potentials estimated for the region.

\section{Conclusions}

Our study provides insight into how the potential availability of forest biomass is spatially distributed across the European continent. We found that the largest total forest biomass potentials per unit of land can be found in northern Europe (including the Baltic countries), central Europe, Slovenia, southwest France and central parts of Portugal. However, a large part of these potentials are already used to produce materials and energy and there is limited scope for further extraction of biomass in these areas. The location of the currently unused forest biomass potentials only partly coincides with regions that currently have high levels of wood production. This has implications for being able to mobilise and process additional wood volumes as necessary infrastructure may not be in place in these areas to facilitate mobilisation. Our results provide insight into those regions in
Europe where policies could focus on an increase of the supply of woody biomass from their resources. Future research on potential biomass availability from European forest should also consider to what extent forest owners would be willing to mobilise additional biomass from their forests and at what costs the estimated potentials could be mobilised.

\section{Abbreviations}

EFISCEN: European Forest Information SCENario model; NUTS: Nomenclature des Unités Territoriales Statistiques

\section{Acknowledgements}

The authors thank all country correspondents who provided recent national forest inventory data for the purpose of this study, as well as all national correspondents and agencies that provided such data during earlier requests or through the internet. The authors also thank three anonymous reviewers for their critical comments on a preliminary version of this article.

\section{Funding}

This work has been funded through the EU 7th framework projects S2BIOM (grant agreement 608622), Trees4Future (grant agreement 284181), and OPERAs (grant agreement 308393), as well as by the Bio Based Industries Joint Undertaking under the EU's H2020 through the TECH4EFFECT project (grant agreement 720757). Opinions expressed in this paper are those of the authors only.

\section{Availability of data and materials}

The forest biomass potentials estimated in this study are available at http:// s2biom.alterra.wur.nl/web/guest/data-downloads. Figure $2 \mathrm{~A}$ is available from https://doi.org/10.5281/zenodo.2553789.

\section{Authors' contributions}

PJV, JBF, PD, MD and ML designed the study and PJV, GMH and SZ implemented the study. PJV analysed the results and wrote the manuscript with contributions from all co-authors. All authors read and approved the final manuscript.

Ethics approval and consent to participate

Not applicable.

Consent for publication

Not applicable.

Competing interests

The authors declare that they have no competing interests.

\section{Author details}

${ }^{1}$ European Forest Institute, Yliopistokatu 6B, Joensuu, Finland. ${ }^{2}$ University of Freiburg - Institute of Forest Sciences - Chair of Remote Sensing and Landscape Information Systems, Tennenbacher Str. 4, 79085 Freiburg, Germany. ${ }^{3}$ Wageningen University and Research, Droevendaalsesteeg 3, 6708, PB, Wageningen, the Netherlands. ${ }^{4}$ European Forest Institute, Platz der Vereinten Nationen 7, 53113 Bonn, Germany.

Received: 8 August 2018 Accepted: 21 January 2019

Published online: 07 February 2019

\footnotetext{
References

Achat DL, Deleuze C, Landmann G, Pousse N, Ranger J, Augusto L (2015a) Quantifying consequences of removing harvesting residues on forest soils and tree growth - a meta-analysis. For Ecol Manag 348:124-141 https://doi. org/10.1016/j.foreco.2015.03.042. Accessed 01 May 2018

Achat DL, Fortin M, Landmann G, Ringeval B, Augusto L (2015b) Forest soil carbon is threatened by intensive biomass harvesting. Sci Rep 5:15991. https://doi.org/10.1038/srep15991

Alberdi I, Michalak R, Fischer C, Gasparini P, Brändli U-B, Tomter SM, Kuliesis A, Snorrason A, Redmond J, Hernández L, Lanz A, Vidondo B, Stoyanov N, Stoyanova M, Vestman M, Barreiro S, Marin G, Cañellas I, Vidal C (2016)
} 
Towards harmonized assessment of European forest availability for wood supply in Europe. For Policy Econ 70:20-29. https://doi.org/10.1016/j.forpol. 2016.05.014

Antón-Fernández C, Astrup R (2012) Empirical harvest models and their use in regional business-as-usual scenarios of timber supply and carbon stock development. Scand J Forest Res 27:379-392. https://doi.org/10.1080/02827581.2011.644576

Asikainen A, Liiri H, Peltola S, Karjalainen T, Laitila J (2008) Forest Energy Potential in Europe (EU27). Finnish Forest Research Institute, Helsinki, p 33

Bell J, Paula L, Dodd T, Németh S, Nanou C, Mega V, Campos P (2018) EU ambition to build the world's leading bioeconomy-uncertain times demand innovative and sustainable solutions. New. Biotech 40:25-30 https://doi.org/10.1016/j.nbt.2017.06.010

Blennow K, Persson E, Lindner M, Faias SP, Hanewinkel M (2014) Forest owner motivations and attitudes towards supplying biomass for energy in Europe. Biomass Bioenergy 67:223-230. https://doi.org/10.1016/j.biombioe.2014.05.002

Bouget C, Lassauce A, Jonsell M (2012) Effects of fuelwood harvesting on biodiversity - a review focused on the situation in Europe. Can J For Res 42 : 1421-1432. https://doi.org/10.1139/×2012-078

Brukas V, Felton A, Lindbladh M, Sallnäs O (2013) Linking forest management, policy and biodiversity indicators - a comparison of Lithuania and southern Sweden. Forest Ecol Manag 291:181-189. https://doi.org/10.1016/j.foreco.2012.11.034

Brunet-Navarro P, Jochheim H, Muys B (2017) The effect of increasing lifespan and recycling rate on carbon storage in wood products from theoretical model to application for the European wood sector. Mitig Adapt Strateg Glob Chang 22:1193-1205. https://doi.org/10.1007/s11027-016-9722-z

Brus DJ, Hengeveld GM, Walvoort DJJ, Goedhart PW, Heidema AH, Nabuurs GJ, Gunia K (2012) Statistical mapping of tree species over Europe. Eur J Forest Res 131:145-157. https://doi.org/10.1007/s10342-011-0513-5

Burg V, Bowman G, Erni M, Lemm R, Thees O (2018) Analyzing the potential of domestic biomass resources for the energy transition in Switzerland. Biomass Bioenergy 111:60-69. https://doi.org/10.1016/j.biombioe.2018.02.007

Daioglou V, Stehfest E, Wicke B, Faaij A, van Vuuren DP (2016) Projections of the availability and cost of residues from agriculture and forestry. GCB Bioenerg 8:456-470. https://doi.org/10.1111/gcbb.12285

de Wit M, Faaij A (2010) European biomass resource potential and costs. Biomass Bioenergy 34:188-202. https://doi.org/10.1016/j.biombioe.2009.07.011

Dees M, Elbersen B, Fitzgerald J, Vis M, Anttila P, Forsell N, Ramirez-Almeyda J, García Galindo D, Glavonjic B, Staritsky I, Verkerk H, Prinz R, Monti A, Leduc S, Höhl M, Datta P, Schrijver R, Zudin S, Lindner M, Lesschen J, Diepen K (2017a) A spatial data base on sustainable biomass cost-supply of lignocellulosic biomass in Europe - methods \& data sources. S2BIOM Project Report 1.6 (version 1.2). Chair of Remote Sensing and Landscape Information Systems, Institute of Forest Sciences, University of Freiburg, Freiburg, p 176. doi:https://doi.org/10.5281/zenodo.1478483

Dees M, Elbersen B, Fitzgerald J, Vis M, Anttila P, Forsell N, Ramirez-Almeyda J, Glavonjic B, Staritsky I, Verkerk H, Prinz R, Leduc S, Datta P, Lindner M, Zudin S, Höhl M (2017b) Atlas with regional cost supply biomass potentials for EU 28, Western Balkan Countries, Moldavia, Turkey and Ukraine. In: S2BIOM Project Report 1.8 (version 1.1). Chair of Remote Sensing and Landscape Information Systems, Institute of Forest Sciences, University of Freiburg, Freiburg, p 105. https://doi.org/10.5281/zenodo.1478500

Di Fulvio F, Forsell N, Lindroos O, Korosuo A, Gusti M (2016) Spatially explicit assessment of roundwood and logging residues availability and costs for the EU28. Scand J Forest Res 31:691-707. https://doi.org/10.1080/02827581.2016.1221128

Díaz-Yáñez O, Mola-Yudego B, Anttila P, Röser D, Asikainen A (2013) Forest chips for energy in Europe: current procurement methods and potentials. Renew Sust Energ Rev 21:562-571. https://doi.org/10.1016/j.rser.2012.12.016

FAOSTAT (2015) Forestry Production and Trade. http://www.fao.org/faostat/en/ \#data/FO. Accessed 12 Oct 2015. FAO statistics division

FAOSTAT (2018) Forestry Production and Trade. http://www.fao.org/faostat/en/ \#data/FO. Accessed 11 Jun 2018. FAO statistics division

Fischer C, Gasparini P, Nylander M, Redmond J, Hernandez L, Brändli U-B, Pastor A, Rizzo M, Alberdi I (2016) Joining criteria for harmonizing European Forest available for wood supply estimates. Case Studies from National Forest Inventories. Forests 7:104. https://doi.org/10.3390/f7050104

Forest Europe (2015) State of Europe's forests 2015. Madrid, p 312

Forest Europe, UNECE, FAO (2011) State of Europe's forests 2011. In: Status and trends in sustainable forest management in Europe. Ministerial conference on the protection of forests in Europe, Forest Europe liaison unit Oslo, Ås, p 337

Gallaun H, Zanchi G, Nabuurs G-J, Hengeveld G, Schardt M, Verkerk PJ (2010) EUwide maps of growing stock and above-ground biomass in forests based on remote sensing and field measurements. Forest Ecol Manag 260:252-261. https://doi.org/10.1016/j.foreco.2009.10.011

Jochem D, Weimar H, Bösch M, Mantau U, Dieter M (2015) Estimation of wood removals and fellings in Germany: a calculation approach based on the amount of used roundwood. Eur J Forest Res 134:869-888. https://doi.org/ 10.1007/s10342-015-0896-9

Jonsell M (2008) The effects of forest biomass harvesting on biodiversity. In: Röser D, Asikainen A, Raulund-Rasmussen K, Stupak I (eds) Sustainable use of forest biomass for energy a synthesis with focus on the Baltic and Nordic region. Springer, Dordrecht, pp 129-154

Jonsson R, Blujdea V, Fiorese G, Pilli R, Rinaldi F, Baranzelli C, Camia A (2018) Outlook of the European forest-based sector: forest growth, harvest demand, wood-product markets, and forest carbon dynamics implications. iForest biogeosciences and Forestry 11:315-328. https://doi.org/10.3832/ifor2636-011

Kilham P, Kändler G, Hartebrodt C, Stelzer A-S, Schraml U (2018) Designing wood supply Scenarios from Forest inventories with stratified predictions. Forests 9:77

Koukios E, Monteleone M, Texeira Carrondo MJ, Charalambous A, Girio F, Hernández EL, Mannelli S, ParajóJC PP, Zabaniotou A (2017) Targeting sustainable bioeconomy: a new development strategy for southern European countries. The Manifesto of the European Mezzogiorno Journal of Cleaner Production 172 3931-3941 https://doi.org/10.1016/j.jclepro.2017.05.020

Lainez M, González JM, Aguilar A, Vela C (2017) Spanish strategy on bioeconomy: towards a knowledge based sustainable innovation. New Biotechnol 40:8795. https://doi.org/10.1016/j.nbt.2017.05.006

Lauri P, Havlík P, Kindermann G, Forsell N, Böttcher H, Obersteiner M (2014) Woody biomass energy potential in 2050. Energy Policy 66:19-31. https://doi. org/10.1016/j.enpol.2013.11.033

Leskinen P, Cardellini G, Gonzalez-Garcia S, Hurmekoski E, Sathre R, Seppälä J, Smyth C, Stern T, Verkerk PJ (2018) Substitution effects of wood-based products in climate change mitigation. From Science to Policy 7. European Forest Institute.

Levers C, Verkerk PJ, Müller D, Verburg PH, Butsic V, Leitão PJ, Lindner M, Kuemmerle T (2014) Drivers of forest harvesting intensity patterns in Europe. Forest Ecol Manag 315:160-172. https://doi.org/10.1016/j.foreco.2013.12.030

Lundmark R, Athanassiadis D, Wetterlund E (2015) Supply assessment of forest biomass - a bottom-up approach for Sweden. Biomass Bioenergy 75:213226. https://doi.org/10.1016/j.biombioe.2015.02.022

Mansuy N, ParéD TE, Bernier PY, Cyr G, Manka F, Lafleur B, Guindon L (2017) Estimating the spatial distribution and locating hotspots of forest biomass from harvest residues and fire-damaged stands in Canada's managed forests. Biomass Bioenergy 97:90-99. https://doi.org/10.1016/j.biombioe.2016.12.014

Masek JG, Cohen WB, Leckie D, Wulder MA, Vargas R, de Jong B, Healey S, Law B, Birdsey R, Houghton RA, Mildrexler D, Goward S, Smith WB (2011) Recent rates of forest harvest and conversion in North America. J Geophys Res 116 : G00K03. https://doi.org/10.1029/2010jg001471

Mola-Yudego B, Arevalo J, Díaz-Yáñez O, Dimitriou I, Freshwater E, Haapala A Khanam T, Selkimäki M (2017) Reviewing wood biomass potentials for energy in Europe: the role of forests and fast growing plantations. Biofuels 8: 401-410. https://doi.org/10.1080/17597269.2016.1271627

Moreno A, Neumann M, Hasenauer H (2017) Forest structures across Europe. Geosci Data J 4:17-28. https://doi.org/10.1002/gdj3.45

Nabuurs G, Pussinen A, van Brusselen J, Schelhaas M (2007) Future harvesting pressure on European forests. Eur J Forest Res 126:391-400. doi:0.1007/ s10342-006-0158-y

Neumann M, Moreno A, Thurnher C, Mues V, Härkönen S, Mura M, Bouriaud O, Lang M, Cardellini G, Thivolle-Cazat A, Bronisz K, Merganic J, Alberdi I, Astrup R, Mohren F, Zhao M, Hasenauer H (2016) Creating a regional MODIS satellitedriven net primary production dataset for European forests. Remot Sens 8:554

Paillet Y, Bergès L, Hjältén J, Ódor P, Avon C, Bernhardt-Römermann M, Bijlsma R-J, De Bruyn LUC, Fuhr M, Grandin ULF, Kanka R, Lundin L, Luque S, Magura T, Matesanz S, Mészáros I, Sebastià MT, Schmidt W, Standovár T, Tóthmérész B, Uotila A, Valladares F, Vellak KAl, Virtanen R (2010) Biodiversity differences between managed and unmanaged forests: meta-analysis of species richness in Europe. Conserv Biol 24:101-112. https://doi.org/10.1111/j.1523-1739.2009.01399.x

Panoutsou C (2017) Modeling and Optimization of Biomass Supply Chains. In: Top-Down and Bottom-up Assessment for Agricultural, Forest and Waste Feedstock, Academic Press

Ranius T, Hämäläinen A, Egnell G, Olsson B, Eklöf K, Stendahl J, Rudolphi J, Sténs A, Felton A (2018) The effects of logging residue extraction for energy on ecosystem services and biodiversity: a synthesis. J Environ Manag 209:409_ 425. https://doi.org/10.1016/j.jenvman.2017.12.048 
Rytter L, Ingerslev M, Kilpeläinen A, Torssonen P, Lazdina D, Löf M, Madsen P, Muiste P, Stener L-G (2016) Increased forest biomass production in the Nordic and Baltic countries - a review on current and future opportunities. Silv Fenn 50:33. https://doi.org/10.14214/sf.1660

Sallnäs O (1990) A matrix model of the Swedish forest. Studia Forestalia Suecica 183:23

San-Miguel-Ayanz J, de Rigo D, Caudullo G, Houston Durrant T, Mauri A (2016) European atlas of forest tree species. Publication Office of the European Union, Luxembourg

Sathre R, O'Connor J (2010) Meta-analysis of greenhouse gas displacement factors of wood product substitution. Environ Sci Pol 13:104-114. https://doi. org/10.1016/j.envsci.2009.12.005

Scarlat N, Dallemand J-F, Monforti-Ferrario F, Nita V (2015) The role of biomass and bioenergy in a future bioeconomy: policies and facts. Environm Develop 15:3-34. https://doi.org/10.1016/j.envdev.2015.03.006

Schelhaas M-J, Hengeveld GM, Heidema N, Thürig E, Rohner B, Vacchiano G, Vayreda J, Redmond J, Socha J, Fridman J, Tomter S, Polley H, Barreiro S, Nabuurs G-J (2018) Species-specific, pan-European diameter increment models based on data of 2.3 million trees. Forest Ecosyst 5:21. https://doi. org/10.1186/s40663-018-0133-3

Searchinger TD, Beringer T, Holtsmark B, Kammen DM, Lambin EF, Lucht W, Raven P, van Ypersele J-P (2018) Europe's renewable energy directive poised to harm global forests. Nat Commun 9:3741. https://doi.org/10.1038/s41467018-06175-4

Sillanpää M, Ncibi C (2017) A sustainable bioeconomy. The green industrial revolution. Springer International Publishing. https://doi.org/10.1007/978-3319-55637-6

Sing L, Metzger MJ, Paterson JS, Ray D (2018) A review of the effects of forest management intensity on ecosystem services for northern European temperate forests with a focus on the UK. For Intl J For Res 91:151-164. https://doi.org/10.1093/forestry/cpx042

Smeets EMW, Faaij APC (2007) Bioenergy potentials from forestry in 2050. Climat Chang 81:353-390. https://doi.org/10.1007/s10584-006-9163-x

Stjepan P, Mersudin A, Dženan B, Nenad P, Makedonka S, Dane M, Špela PM (2015) Private forest owners' willingness to supply woody biomass in selected south-eastern European countries. Biomass Bioenergy 81:144-153. https://doi.org/10.1016/j.biombioe.2015.06.011

Teobaldelli M, Somogyi Z, Migliavacca M, Usoltsev VA (2009) Generalized functions of biomass expansion factors for conifers and broadleaved by stand age, growing stock and site index. Forest Ecol Manag 257:1004-1013. https://doi.org/10.1016/j.foreco.2008.11.002

Thurner M, Beer C, Santoro M, Carvalhais N, Wutzler T, Schepaschenko D, Shvidenko A, Kompter E, Ahrens B, Levick SR, Schmullius C (2013) Carbon stock and density of northern boreal and temperate forests. Glob Ecol Biogeogr 23:297-310. https://doi.org/10.1111/geb.12125

Tomppo E, Geschwantner T, Lawrence M, McRoberts RE (2010) National Forest Inventories - pathways for common reporting, springer Heidelberg. In: Dordrecht. London, New York

Tum M, McCallum I, Kindermann G, Günther KP, Schmid E (2013) Sustainable bioenergy potentials for Europe and the globe. Geoinformatics \& Geostatistics: An Overview. https://doi.org/10.4172/2327-4581.S1-010

UNECE-FAO (2000) Forest Resources of Europe, CIS, North America, Australia, Japan and New Zealand. Contribution to the Global Forest Resources Assessment 2000, UN, New York and Geneva

UNECE-FAO (2010) Forest product conversion factors for the UNECE region. ECE/ TIM/DP/49. United Nations. Timber section, Geneva, p 38

UNECE-FAO (2011) The European Forest sector outlook study II. 2010-2030. In: ECE/TIM/SP/28. United Nations, Geneva

Vance ED, Prisley SP, Schilling EB, Tatum VL, Wigley TB, Lucier AA, Van Deusen PC (2018) Environmental implications of harvesting lower-value biomass in forests. Forest Ecol Manag 407:47-56. https://doi.org/10.1016/j.foreco.2017.10.023

Vanguelova El, Pitman R, Benham S, Perks M, Morison JIL (2017) Impact of tree stump harvesting on soil carbon and nutrients and second rotation tree growth in mid-Wales, UK. Open J For 7(1):21. https://doi.org/10.4236/ojf.2017.71005

Verkerk PJ, Anttila P, Eggers J, Lindner M, Asikainen A (2011) The realisable potential supply of woody biomass from forests in the European Union. Forest Ecol Manag 261:2007-2015. https://doi.org/10.1016/j.foreco.2011.02.027

Verkerk PJ, Levers C, Kuemmerle T, Lindner M, Valbuena R, Verburg PH, Zudin S (2015b) Data from: mapping wood production in European forests. Dryad Dig Reposit. https://doi.org/10.5061/dryad.mk067.
Verkerk PJ, Levers C, Kuemmerle T, Lindner M, Valbuena R, Verburg PH, Zudin S (2015a) Mapping wood production in European forests. Forest Ecol Manag 357:228-238. https://doi.org/10.1016/j.foreco.2015.08.007

Verkerk PJ, Schelhaas MJ, Immonen V, Hengeveld G, Kiljunen J, Lindner M, Nabuurs GJ, Suominen T, Zudin S (2016) Manual for the European Forest Information Scenario model (EFISCEN 4.1). EFI Technical Report 99. European Forest Institute, Joensuu, p 49

Vis M, Dees M (2011) Biomass Resource Assessment Handbook: Harmonisation of Biomass Resource Assessments. In: Best Practices and Methods Handbook. VDM Verlag Dr, Müller, Saarbrücken

Wallenius T, Niskanen L, Virtanen T, Hottola J, Brumelis G, Angervuori A, Julkunen J, Pihlström M (2010) Loss of habitats, naturalness and species diversity in Eurasian forest landscapes. Ecol Indic 10:1093-1101. https://doi.org/10.1016/j. ecolind.2010.03.006

Walmsley JD, Godbold DL (2010) Stump harvesting for bioenergy - a review of the environmental impacts. Forestry 83:17-38. https://doi.org/10.1093/ forestry/cpp028

Wendland KJ, Lewis DJ, Alix-Garcia J, Ozdogan M, Baumann M, Radeloff VC (2011) Regional- and district-level drivers of timber harvesting in European Russia after the collapse of the Soviet Union. Global Environm Change 21:12901300. https://doi.org/10.1016/j.gloenvcha.2011.07.003

\section{Submit your manuscript to a SpringerOpen ${ }^{\circ}$ journal and benefit from:}

- Convenient online submission

- Rigorous peer review

- Open access: articles freely available online

- High visibility within the field

- Retaining the copyright to your article

Submit your next manuscript at $\boldsymbol{\nabla}$ springeropen.com 